\title{
ANALYSIS OF HISTORICAL SERIES OF MAMIRAUÁ LAKE LEVEL (PRELIMINARY STUDY)
}

\author{
Nayandra Carvalho da Silva ${ }^{1}$, Javier Tomasella ${ }^{2}$, Antonio Ocimar Manzi ${ }^{3}$ and Maria Cecilia \\ Rosinski Lima Gomes ${ }^{4}$
}

\author{
${ }^{1}$ National Institute of Amazonian Research - INPA. Manaus-Amazonas, Brazil. \\ ${ }^{2,3}$ National Institute for Space Research - INPE. São José dos Campos-São Paulo, Brazil. \\ ${ }^{4}$ Mamirauá Sustainable Development Institute - IDSM, Tefé-Amazonas, Brazil.
}

Email: nayandracarvalho10@gmail.com, javier.tomasella@ cemaden.gov.br, antonio.manzi@inpe.br, cecilia@mamiraua.org.br

Received: Oct 02 ${ }^{\text {th }}, 2019$

Accepted: Oct 31 ${ }^{\text {th }}, 2019$

Published: December 02 ${ }^{\text {th }}, 2019$

Copyright @2016 by authors and Galileo Institute of Technology and Education of the Amazon (ITEGAM).

This work is licensed under the Creative Commons Attribution International License (CC BY 4.0).

https://creativecommons.org/licen ses/by/4.0/

\begin{abstract}
Amazonian floodplains can be defined as areas bathed by white or muddy rivers; Its main feature is the amount of suspended materials that are transported during the flood and drought dynamics of the rivers and lakes in the region. The objective of this work was to analyze the historical water level series of Mamirauá Lake. We used 25 years of data from the lake performed by the Mamirauá Institute Fluviometric Monitoring since 1990. The descriptive statistics technique was used for the maximum, minimum and average quotas of the monitoring years, as it sought to verify the level relationship. of the lake with the occurrence of extreme events that have happened over the years. The results obtained were: the lowest level of the data series, with a value of 21.7 m.a.n.m was recorded in 1995 and the highest in 1999 was 38.6 m.a.n.m., that year the Amazon basin suffered one of the largest floods related to the La Niña phenomenon. Given the results analyzed, the research concluded that the water level of Mamirauá Lake did not change in years of occurrence of extreme events, as was verified in the years of extreme drought (2005 and 2010).
\end{abstract}

Keywords: Extreme event, severe droughts, climate change, Amazon floodplain.

\section{INTRODUTION}

The Amazon is known for its vast territorial extension and large interannual rainfall variability that directly affect the hydrological dynamics of one of the largest rivers in the world, the Amazon River. Due to this high rainfall and seasonal distribution, periodic floods occur every year and are known as: flood and ebb periods [1] [2] [3]. Wetlands or wetlands are periodically flooded aquatic environments with plant and animal communities that adapt to this dynamic [4].

In the context of national territory, wetlands are mainly studied in the Pantanal region, in the states of Mato Grosso and Mato Grosso do Sul, as it is one of the largest floodplains in the world [5]; [6]; [7]; [8].

Due to the hydrological dynamics (flood and dry), the rivers and lakes of the Amazon region carry large amounts of sediments, which are rich in nutrients and supply the entire ecological functioning of floodplains known as floodplains. Amazonian floodplains are of great importance to both the biota and the periodic flood pulse of flooded forests [9].
The Mamirauá Sustainable Development Reserve is considered one of the largest wetlands with Amazonian floodplain forests. In the Amazon, because it is a tropical and humid area, extreme weather conditions cause a decrease in rainfall, as well as a reduction in river levels and navigability. In recent years, increased floods and prolonged droughts have become more frequent [5]; [10].

Hydrological studies to understand the functioning of the Amazon basin and the dynamics of rivers and floodplain lakes make use of mathematical models [11]; [12], which can represent the dynamics of individual lakes and large basins as well as the inclusion of water balance.

However, information from the literature indicates that [13];[14];[15];[16] water dynamics has been increasingly affected by so-called extreme events (events that anomalously affect river dynamics as well as temperature and precipitation in these regions). More recent studies [17];[15];[18]; [19] conclude that since the great drought of 2005, caused by anomalous sea temperature warming in the ocean peaceful, these events have become more frequent (Fig.2). 
Thus, studying how such events affect the dynamics of the Amazonian floodplain lakes and river is necessary, since with more frequent events of severe floods and droughts the life of the local population, the economy and the aquatic life of the forest are affected. Extreme droughts cause navigational difficulties and fish mortality [17], while floods and repiquetes (rapid floods) cause crop loss at times of the year when planting would be essential for subsistence [19].

Given the above, this study aims to evaluate the effect of extreme events on the hydrological regime of the floodplain of Mamirauá from the analysis of historical series of the lake.

\section{MATERIALS AND METHODS}

Mamirauá Lake (03 ${ }^{\circ} 06$ '55 "S and $\left.64^{\circ} 47^{\prime} 50^{\prime} \mathrm{W}\right)$ is located within the Mamirauá Sustainable Development Reserve (RDSM) in the Midwest of Amazonas State which has an area of $1,240,000$ ha. of floodplain forests that are annually flooded and bounded by the Solimões, Japurá and Auati-Paraná rivers [20].

This study aims to discuss the behavior of Mamirauá Lake (Fig. 1) under the effect of hydrological regime with water level measurements (quotas) monitored by the Mamirauá Institute since 1990 (https://mamiraua.org.br/pt-br/pesquisa-emonitoramento/monitoramento/fluviometrico/) [21]. It should be noted that this is a preliminary study.

A 25-year series of lake level measurement (1992-2017) was used in this study. The technique of descriptive statistics of maximum, minimum and average quotas of the years of fluviometric monitoring was used, since it seeks to verify the lake level relationship with the occurrence of extreme events that happened over the years.

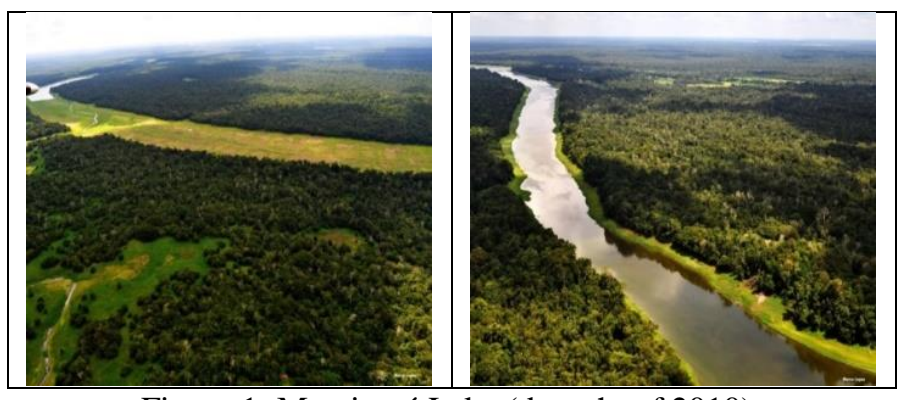

Figure 1: Mamirauá Lake (drought of 2010). Source: [21].

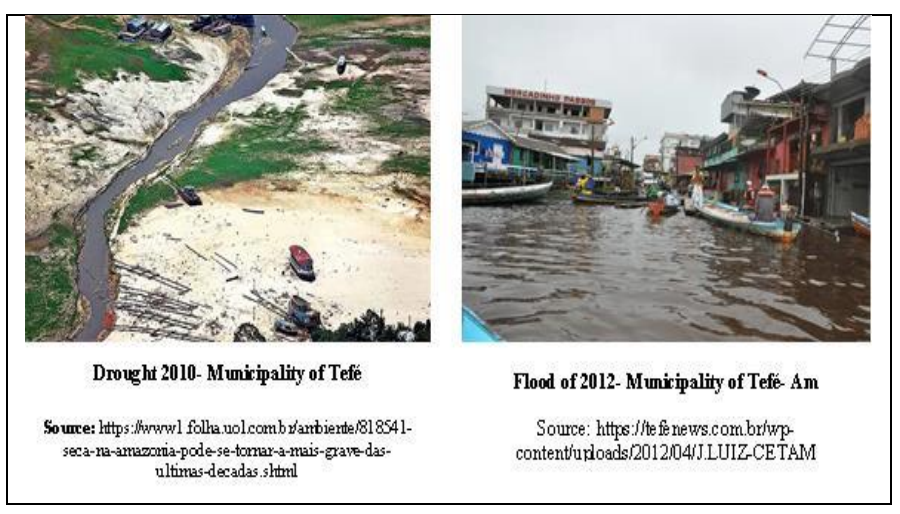

Figure 2: Extreme events in the municipality of Tefé-AM. The left the extreme drought event in 2010 and the right the severe flood event in 2012.

\section{RESULTS AND DISCUSSION}

Results are shown in the figures below.

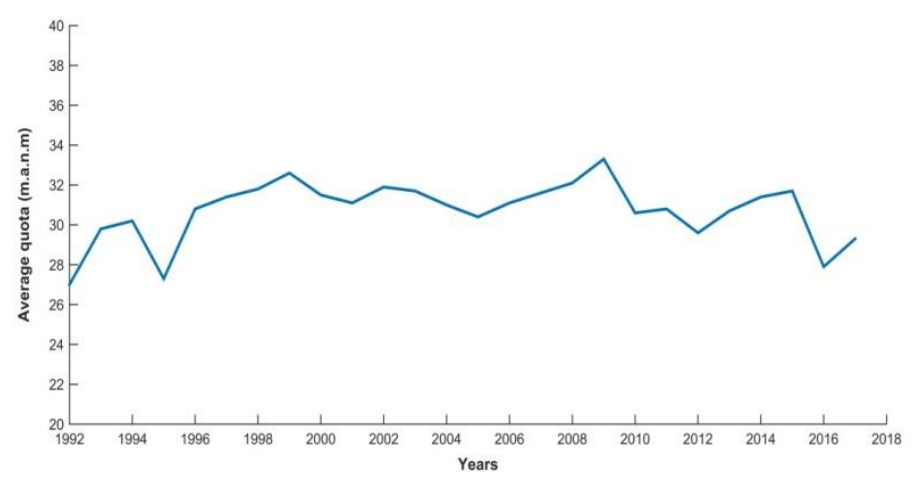

Figure 3: Quotas of the historical series. Source: Authors, (2019).

The results presented in Figure 3 show that the average level of Mamirauá lake was 30.7 m.a.n.m. The years with the lowest shares were 1995, 2012 and 2017; in 1995 the quota was the lowest in the entire data series, with a value of 21.7 m.a.n.m (meters above sea level). In 2012 the minimum quota was 22 m.a.n.m and in 2017 it was 22.4 m.a.n.m.

The highest quota years in the data series were 1999, 2009 and 2011. The highest quota was 38.6 m.a.n.m. in 1999 which was one of the record floods of the Amazon River related to the La Niña event (heavy rain in the Amazon region); in 2009 it had a quota of 38.3 m.a.n.m and 2011 it had a quota of 37.4 m.a.n.m.

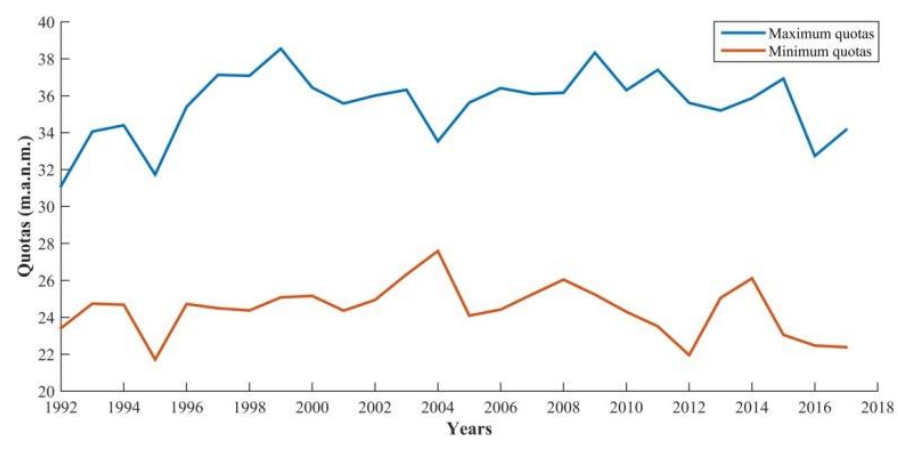

Figure 4: Maximum and minimum quotas of Mamirauá Lake. Source: Authors, (2019).

The relationships of minimum and maximum quotas with extreme events have been verified in more recent literature studies in floodplain rivers and lakes. With the analysis of the data of this study it was observed that in 1999 (severe flood in the Amazon basin) the water level of the lake was above the average of the years in which there were no extreme events (the lake level in that year may have been influenced by the main river, Solimões river). In 2005, when the Amazon basin suffered from one of the most severe droughts related to the rise in surface temperature of the North Tropical Atlantic Ocean, the minimum quota in Mamirauá Lake was 24.1 m.a.n.m. and the maximum was 35.6 m.a.n.m and was therefore not severely affected. Already in 2010, when there was an extreme drought driven by the rising temperature of the Atlantic Ocean and the El Niño event (event that causes periods of less precipitation in the central Amazon region), the minimum quota was 24.3 m.a.n.m. and the maximum 36.3. m.a.n.m. (Fig.4). According to literature studies, extreme drought events in the Amazon are strongly related to El Niño. 


\section{CONCLUSION}

From the results described above, it can be concluded that the water level of Mamirauá lake did not change in years of occurrence of extreme events, this could be verified in the years 2005 and 2010 (extreme droughts), the years that presented The lowest water levels were those of 1995, 2012 and 2017 (drought events). Already the highest quotas were observed in the years 1999, 2009 and 2011 (flood events). New analysis questions can be raised with this study as: 1) The duration of floods has increased in recent years; 2) There are differences between the hydrological dynamics of floodplain lakes in the years of extreme events; and 3) Seasonal variation between flood and ebb has increased in recent decades. To refute the study further, a detailed analysis of the quotas and comparison with data from other floodplain lakes with characteristics similar to Mamirauá floodplain is suggested. In this sense, it is noteworthy that this work is part of a preliminary study that aims to analyze the effects of extreme events on the dynamics of lakes and rivers of the Amazon floodplain in which the Mamirauá lake monitoring data are inserted. More research is expected to be conducted within the theme, as the investigation of extreme events with the potential relationship of climate change can be of great contribution to society.

\section{REFERENCES}

[1] Serrão, Edivaldo Afonso de Oliveira et al., Avaliação da seca de 2005 e 2010 na Amazônia: Análise da Bacia hidrográfica do rio Solimões. Revista Geografia Acadêmica, v.9, n.2,p. 5-20, 2015.

[2] Marengo, J. A; Nobre, C. A; Tomasella, J; Cardoso, M. F; Oyama, M. D (2008b). Hydro-climatic and ecological behaviour of the drought of Amazonia in 2005. Phil Trans R Soc B363:17731778. doi:10.1098/ rstb.2007.0015.

[3] Borges Pedro, J. P. et al. Influence of the Hydrological Cycle on Physical and Chemical Variables of Water Bodies in The Várzea Areas of The Middle Solimões River Region (Amazonas, Brazil). Revista Uakari, Belém, v. 9, n. 2, p.33-47, 2013.

[4] Junk, W. J., Piedade, M. T. F., Lourival, R., Wittmann, F., Kandus, P., Lacerda, L. D.,Agostinho, A. A. (2013). Brazilian wetlands: their definition, delineation, and classification for research, sustainable management, and protection. Aquatic Conservation: Marine and Freshwater Ecosystems, 24(1), 522. doi:10.1002/aqc.2386.

[5] Conchy, Tainá Sampaio Xavier. Impacto de mudanças do uso de solo sobre a hidrologia numa planície de inundação amazônica, caso de estudo: o lago Janauacá . 2018. Dissertação (Mestrado em Clima e Ambiente) - Instituto Nacional de Pesquisas da Amazônia, Universidade do Estado do Amazonas, Manaus, 2018.

[6] Piedade, Maria Teresa Fernandez et al., Iniciando a viagem pelas Áreas Úmidas Amazônicas. In: Conhecendo as áreas úmidas amazônicas: uma viagem pelas várzeas e igapós. Manaus : Editora INPA, 2015. p. 15-22.

[7] Rosa, Sejana Artiaga et al. Entre a água e a terra: Áreas Úmidas (AUs). In: Conhecendo as áreas úmidas amazônicas: uma viagem pelas várzeas e igapós. Manaus : Editora INPA, 2015. p.23-31.

[8] Marinho, Tatiana Andreza da Silva et al. Tipos de Áreas Úmidas Amazônicas. In: Conhecendo as áreas úmidas amazônicas: uma viagem pelas várzeas e igapós. Manaus: Editora INPA, 2015. p.33-40.
[9] Junk, Wolfgang J. ; Furch, Karin. A general review of tropical South American floodplains. SPB Academic Publishing, v. 2, n. 4, p. 231-238, 1993.

[10] Marengo, J.A.; Schaeffer, R.; Pinto, H.S.; Zee, D.M.W. Mudanças climáticas e eventos extremos no Brasil. Rio de Janeiro: FBDS, 2009.

[11] Lesack, L. F.; Melack, J. M. 1995. Flooding hydrology and mixture dynamics of lake water derived from multiple sources in an Amazon floodplain lake. Water Resources Research, 31(2), 329345 .

[12] Bonnet, M. P., (2008). Floodplain hydrology in an Amazon floodplain lake (Lago Grande de Curuaí). Journal of Hydrology, 349, 18-30. doi:10.1016/j.jhydrol.2007.10.055.

[13] Marengo, J. A., J. Tomasella, L. M. Alves, W. R. Soares, and D. A. Rodriguez (2011), The drought of 2010 in the context of historical droughts in the Amazon region, Geophys. Res. Lett., 38, L12703, doi: 10.1029/2011GL047436.

[14] Marengo J. A.; Nobre. C.; Tomasella, J.; Oyama, M.; Oliveira, G. S.; Oliveira, R.; Camargo, H.; Alves, L. M.; Brown, I. F. The drought of Amazônia in 2005. Journal of Climate, n. 21, p. 495516,2008

[15] Barichivich, Jonathan et al. Recent intensification of Amazon flooding extremes driven by strengthened Walker circulation. Science Advances, p.1-7, 2018.

[16] Tomasella, J.; Pinho, P.F., Borma, L.S., Marengo, J.A., Nobre, C.A., Bittencourt, O.R.F.O., Prado, M.C.R., Rodriguez, D.A., Cuartas, L.A., 2013. The droughts of 1997 and 2005 in Amazonia: floodplain hydrology and its potential ecological and human impacts. Climatic Change $116 \quad$ (3-4), 723-746. http://dx.doi.org/10.1007/ s10584-0120508-3.

[17] Coomes, O.T. et al. 2016. Amazon river flow regime and flood recessional agriculture: Flood stage reversals and risk of annual crop loss. Journal of Hydrology 539 (2016) 214-222. http://dx.doi.org/10.1016/j.jhydrol.2016.05.027.

[18] Batista, E.S.; Schöngart, J. 2018. Dendroecology of Macrolobium acaciifolium (Fabaceae) in Central Amazonian floodplain forests. Acta Amazônica 48: 311-320. http://dx.doi.org/10.1590/1809-4392201800302.

[19] Ronchail, Josyane et al., The flood recession period in Western Amazonia and its variability during the 1985-2015 period. Journal of Hydrology: Regional Studies 15 (2018) 16-30. https://doi.org/10.1016/j.ejrh.2017.11.008.

[20] Ramalho, E. E. et al. Ciclo hidrológico nos ambientes de várzea da Reserva de Desenvolvimento Sustentável Mamirauá Médio Rio Solimões, período de 1990 a 2008. Revista Uakari, v.5, n.1, p. 61-87, jun. 2009.

[21] Instituto de Desenvolvimento Sustentável Mamirauá. Banco de dados fluviométrico da Reserva de Desenvolvimento Sustentável Mamirauá. Acessado em 17/04/2019 . Disponível em: http://mamiraua.org.br/pt-br/pesquisa-e-

monitoramento/monitoramento/fluviometrico. 